Article

\title{
Push/Pull Factors, Networks and Student Migration from Côte d'Ivoire to France and Switzerland
}

\author{
Franck Dago $^{1, *}$ and Simon Barussaud ${ }^{2}$ \\ ${ }^{1}$ Department of Sociology, University Félix Houphouët-Boigny, Abidjan, Côte d'Ivoire; E-Mail: franck.dago.ufhb@gmail.com \\ 2 IDESO-Institute of Demographic and Socioeconomic Studies, University of Geneva, 1201 Geneva, Switzerland; \\ E-Mail: sim.barussaud@gmail.com \\ * Corresponding author
}

Submitted: 30 September 2020 | Accepted: 15 December 2020 | Published: 25 March 2021

\begin{abstract}
Since 2011, the Ivorian government has invested heavily in higher education to meet its labour market's growing demand. In this article, we analyse the drivers of Ivorian student mobility from Côte d'Ivoire to France and Switzerland, highlighting the central role of migrant networks. We focus on the decision-making process and find that migration networks play an important role at every step: from initial aspirations to concrete plans and efforts to study abroad. Using 38 in-depth interviews and two focus groups with Ivorian students who aspire to study in France and Switzerland, members of the education board, migration officers, and members of the Ivorian diaspora, we reveal that the functioning of the Ivorian higher education system is a factor of uncertainty for many students who consider that salvation can only come from migration. In addition, social representations linked to foreign diplomas inspire Ivorian students to choose international mobility. Migrant networks further encourage Ivorian students to move abroad because stories from successful migrants sharing their mobility experience are coupled with the provision of key resources to support mobility projects.
\end{abstract}

\section{Keywords}

Côte d'Ivoire; decision-making process; migration aspirations; migration network; student mobility

\section{Issue}

This article is part of the issue "Decision-Making under Uncertainty: African Migrants in the Spotlight" edited by Didier Ruedin (University of the Witwatersrand, South Africa / University of Neuchâtel, Switzerland).

(C) 2021 by the authors; licensee Cogitatio (Lisbon, Portugal). This article is licensed under a Creative Commons Attribution 4.0 International License (CC BY).

\section{Introduction}

For a long time, student migration has been considered, to some extent, as an understudied phenomenon, although new studies have been conducted in the last few years (Bereni \& Rubi, 2015; Dia, 2014; King \& Raghuram, 2012). Indeed, the scientific literature points to a growing interest among researchers in this phenomenon, related issues and its contemporary dynamics. Since the beginning of the 21st century, international student mobility has increased rapidly (Gérard \& Voin, 2013; Renggli \& Riaño, 2017) and in 2015 the OECD estimated that there were 5 million international students (Renggli \& Riaño, 2017). We also perceive a significant concen- tration of student mobility flows to Western Europe and Northern America (Campus France, 2018) even if south-south international student migrations are increasing (Razafimahefa \& Raynal, 2014). A major and growing part of this student inflow comes from developing countries, with sub-Saharan countries having the highest international student mobility rates (Campus France, 2019). This rise in student mobility (especially towards Western Europe) seems to be a consequence of the implementation of educational policies and the development of the knowledge economy, which aims to attract highly qualified students from around the world.

Despite the comparatively low levels of education on the continent on average (Efionayi \& Piguet, 2014), 
African student mobility is growing rapidly as a result of youth bulge (demographic growth) and the positive outcomes of educational policies promoting universal access to school and the great expansion of primary and secondary education (Razafimahefa \& Raynal, 2014). In West Africa, national tertiary educational systems have a limited capacity to absorb all these new tertiary students, and many universities face governance problems. Consequently, the leading causes of African student mobility are related to push factors such as the low quality of university education and lack of facilities, as well as frequent strikes and social turmoil inside campuses (Efionayi \& Piguet, 2014; Mary, 2014).

To overcome these challenges of governance and education quality, the government of Côte d'Ivoire has made extensive investments in its education system to make it more attractive and competitive. Indeed, in 2011, 168 million euros were invested in renovating the main universities (the University Félix Houphouët-Boigny, the University Nangui Abrogoua of Abidjan and the University Alassane Ouattara of Bouaké) and creating new ones (the University Peloforo Gon Coulibaly of Korhogo, the University Jean Lorougnon Guédé of Daloa and the University of Man). These investments were especially focused on tertiary education and the creation of new universities that fostered the adoption of the French-style licence-master-doctorate (LMD) system for better recognition of Ivorian diplomas. In addition, the Ivorian government reinforced its partnerships with universities in OECD countries such as France, a strategic partner in terms of tertiary education and scientific research. This partnership has strengthened the French presence in the Ivorian higher education system, resulting in the issuance of 56 French university titles by Ivorian higher education institutions during the 2018-2019 academic year. As part of this bilateral partnership, French universities want to significantly increase the number of university diplomas delivered to Ivorian students from 56 (in 2018) to 100 in 2022.

Despite these initiatives, we observe that the number of Ivorian students abroad is rising (9,679 in 2014, 10,611 in 2015 and 12,229 in 2016). The Campus France (2018) report noticed that France is the first destination country for these students (7,135 in 2017 and 8,085 in 2018). We also observe an important diversification of destination countries among Ivorian students (the United States, Canada, China, India, Morocco, Switzerland, etc.).

Migration networks and information play an important role in realizing one's student mobility project (Efionayi \& Piguet, 2014; Touré, 2015). International mobility projects are rarely individual projects, and many actors and members of the student's network contribute directly to the realization of a migration project. This contribution could involve various actors that provide strategic resources to the potential migrant (such as information, money, connections, tips and advice; Dako-Gyeke, 2015). Even if the role of these networks is often analy- sed in quantitative studies (Touré, 2015), qualitative approaches could also reveal the complexity of migration networks' influence on student mobility and the kind of resources provided to the potential migrant.

These observations led us to focus on the following research questions: What are the main drivers (push and pull factors) of student mobility in the Ivorian context? To what extent do migration networks influence the social construction of student mobility, and how do they influence the decision-making process of students? What kind of key resources do they provide to ease this migration project?

\subsection{Push/Pull Factors, Migration Networks and Sub-Saharan African Student Mobility}

Many references tackle the migration network and its influence on nurturing migration flows and immigrant integration (see, among others, Haug, 2008; Mazzella, 2016). Haug (2008) explained the influence of social capital in migration decision-making processes and its influence on chain migrations. She argues that the possession of social capital in host countries has a positive impact on emigration and return migration, defining migration networks as "a composite of interpersonal relations in which migrants interact with their family or friends" (Haug, 2008 , p. 588). Migration networks facilitate migration by providing financial support, accommodations, and help in crossing borders (legally or illegally). Migration networks involve migrants, non-migrants (families sited in home countries, for instance) and greatly foster labour migration. Haug (2008) proposes five hypotheses that explain the relation between migration networks and the migration decision-making process:

1. The affinity hypothesis analyses the influence of the links to a community that can prevent migration and the role played by the presence of relatives in the destination country.

2. In the information hypothesis, when the migration candidates have relatives sited in many places, their interest in migration is more significant. Foreign places look more attractive because the network members provide information that influences the decision-making process.

3. In the facilitating hypothesis, the members of the network sited in the host country promote this place, making it likely to foster the integration of migration candidates.

4. The conflict hypothesis states that familial conflict or disputes in the home country may also represent a push factor for migrants who want to gain some friendship and a sense of autonomy.

5. The encouraging hypothesis describes when families incite their members to carry out labour migration to increase their households' income and to create new opportunities abroad. 
This analytical framework appears relevant for the present study as it allows an understanding of different aspects of the importance of migration networks in decision-making processes such as the composition of the networks (families, relatives and migrants) and the resources it provides (information, financial support, assistance for integration, etc.). However, it does not stress the push and pull factors that explain student migration, except, to some extent, the conflict hypothesis. In our case, such information is available in the increasing publications related to international student migrations. These publications sometimes stress international student migration factors from developing to developed countries (Mary, 2014). Student migration is often presented as a consequence of (pull and push) factors such as the unequal development of science and technology globally and the implementation of certain educational policies that aim to attract the most qualified migrants (Campus France, 2019).

Campus France (2019) highlights a set of push factors leading African students to migration: the lack of qualification of higher education teachers, the lack of doctoral programs, the low recognition of universities, teachers and their work internationally, the low rate of professional integration of graduates due to the mismatch between the training offered and the real needs of the labour market, etc.

Kabbanji, Levantino, and Ametepe (2013) also noticed a significant increase in international student migration from sub-Saharan countries in the last two decades due to the inability of higher education institutions to meet the growing demand for education. In addition, the decision-making process mainly depends on the availability of information, the reputation of the higher education system of the potential host country, the recognition of qualifications acquired abroad in the home country, and geographic proximity. Migration networks also have an important role: Most international students in France say they have family members there before their arrival (Borgogno and Volenweider-Andersen, as cited in Kabbanji et al., 2013).

Fall (2010) addressed the importance of migration networks in every stage of international student migration processes. He stated that Senegalese migrant candidates choose their host countries according to the pre-existing diaspora network living in the city where the migrant plan to study. He also showed off student families as key actors of migration networks. Indeed, Senegalese families and relatives encourage students to move to OECD countries to gain cultural and social capital. In addition, Fall (2010) highlighted some push factors that heavily influence Senegalese student mobility, which included the low quality of the higher education system in Senegal, the unavailability of specific training programmes, strikes. These pushing effects are exacerbated by the pulling factors of the destination universities, which are more attractive and competitive. For instance, France possesses several pull factors: lan- guage, the 'low' cost of schooling and the value of diplomas issued by universities in these countries. Otherwise, Efionayi and Piguet (2014), who studied international student migration from Côte d'Ivoire, revealed the importance of transnational networks. In fact, migration decision making depends on migration networks and the surroundings in the home country. As an essential part of the network-which has a key role in the conception of mobility projects - the centrality of families is underlined. According to Efionayi and Piguet (2014), in Côte d'Ivoire, moving abroad for studies provides important symbolic capital because foreign diplomas are highly valued.

In the wake of this current research, Mankou (2014) also addressed international student migration issues. Focusing on the Cameroonian case, he noted that the deterioration of Cameroon's economic conditions and its effects on the education system leads students to migrate to northern countries. These migrations are sometimes facilitated by the granting of scholarships to students and researchers. Moreover, Mankou (2014) remarked that student migration is sometimes a pretext for simply relocating to northern countries and obtaining access to their attractive labour market. He emphasized the significant role played by the migration networks (notably the family diaspora's members) who provide financial support and accommodation and who facilitate migrant students' integration. Mary (2014) underlined how the Malian elite used their networks to facilitate the international migration of students to maintain their social and political domination over the rest of society.

Charlier and Croché (2010) analysed the role played by families as key actors in migration networks. They noticed that some families help their members move abroad for studies because this mobility fosters social distinction (for both students and their families) and allows them to maintain their social reputations.

Dako-Gyeke (2015) studied youth migration projects in Ghana and pointed out that their willingness to move abroad is much more developed than that of other societal groups. However, this migration project is not always related to the youth's personal ambition, but it is integrated into a familial strategy for developing and diversifying their international network. With this in mind, these families encourage students to move to northern universities and even decide for them. In return, these students have certain social obligations to help relatives join them in the host country (chain migration), including providing them with information and facilitating their integration.

This overview of the literature reveals that student migration from sub-Saharan Africa to northern countries is generally a consequence of the combination of push factors like the lack of qualification of higher education teachers, the lack of doctoral programs, the low recognition of many sub-Saharan universities, etc., and pull factors such as the value of diplomas issued by the uni- 
versities of northern countries, for instance. In addition, migration networks play a key role in this by providing information, financial support and help for integration in the host countries. This literature review also presents the selected conceptual and analytical frame used to construct data collection tools and the analysis.

\section{Methodology}

This study is based on a qualitative methodology that fosters an in-depth understanding of the studied phenomenon, relying on the participants' viewpoints and insights into the social context where the phenomenon occurs (Cresswell, 2014). This approach appeared to be the most suitable, as it allows capturing students' views about the Ivorian higher education system, their perceptions of foreign studying conditions and the value of diplomas to analyse how migration networks influence decision-making and the types of resources provided by networks for the realization of the youth mobility project.

The study was carried out in Abidjan, Cote d'Ivoire, from November 2018 to January 2019 with participants from several public and private universities. We also attended an informational session at the French Cultural Institute and a meet-up organized by private agencies that promote student migration, where we interviewed some Ivorian students who wanted to study in French universities. The Swiss Centre for Scientific Research (SCSR) provided us with a list of candidates for Swiss government scholarships (bourse de la Confederation). We selected candidates from this list to conduct our interviews. In addition, our investigation included members of the Ivorian education board, migration officers from Campus France and the SCSR, and members of the Ivorian diaspora.

We carried out 38 individual in-depth interviews and two focus group discussions. The use of these data collection techniques was driven by a desire to capture the participants' individual experiences, compare their points of view, and triangulate our sources (Baribeau \& Germain, 2010). Data collection was conducted in French. Collected data were analysed through the method proposed by Merriam and Tisdell (2016). This method has been implemented with specialised software (Max QDA 2018). Concretely, the first stage of the analysis process was the full transcription of all the interviews carried out. Once the transcriptions were completed, the corpus was coded, sometimes with predefined codes, sometimes with codes emerging directly from empirical data. The second stage of the analysis process was gathering the codes to create categories, which are concepts used to describe the different aspects of the studied phenomenon (Merriam \& Tisdell, 2016). The third stage of the process was linking categories to describe the social construction of Ivorian student migration to France and Switzerland by focusing on the push/pull factors and the role of migration networks.
However, we specify that the data collection and analysis processes were carried out iteratively to ensure that saturation was reached.

\section{Main Findings}

\subsection{Push/Pull Factors Leading to Ivorian Students' Migration}

According to the participants, in Ivorian public universities, regular strikes, violence and the particular way the otherwise French-style LMD is implemented leads many students to choose to move abroad. In fact, recurrence and the length of students and staff strikes negatively affect these universities' reputation and academic schedules. These strikes sometimes rise to the level of clashes between police officers and students within the university campus. This situation is illustrated by Aurelia, a participant who attended a public university before shifting to the private Catholic University of West Africa to avoid this instability issue:

I was admitted into a public university right after I graduated from high school. I did not know that things were like this, that there were regular strikes. One day, there was a clash between the police and the students. That day, we were in the middle of a class and people started to run around. There were regular incidents like this. Sometimes, we would go for a month without going to college. I could not continue to study in such a bad condition, so I have decided to move to a private university.

Delays in academic programmes, which are a direct consequence of regular strikes, lead to overlaps in academic years. For example, in January 2019, the Department of Law, Administrative and Political Sciences at the University Félix Houphouët-Boigny was still organizing exams for the 2017-2018 academic year. This situation nurtures feelings of frustration and bitterness among public university students who think that they are disadvantaged compared to international students. This erratic functioning is a factor of uncertainty for many students who consider that salvation can only come from migration.

Even though private universities do not face strikes and schedule delays, Ivorian students face some structural constraints, such as corruption and bad governance, that justify their desire to move abroad. In addition, some participants argue that the conditions for admission to a research masters or doctorate programme at a public university are more restrictive due to a lack of university resources and employment opportunities. Moreover, Ivorian students face some difficulties accessing university residences and managing their daily urban transport between their house and the campus. These problems could also represent a push factor that determines Ivorian students' aspirations for 
international mobility, as share by Jean-Philippe at the Department of Law, Université des Lagunes, Abidjan:

My sister and I used to wake up at 3:30 AM. We attended the University Félix Houphouët-Boigny. We woke up at 3:30 AM because we did not want to miss bus 49, which connects the Abobo area to the university, in order to be in our amphitheatres at 6:00 AM. We had to be there early to get a seat. We used to go back home, on the same bus, at 9:00 PM. We could hardly revise our courses, but we tried....We preferred to stay in our amphitheatres after the class for revising for two hours before going back home.

In addition to the structural factors mentioned, the quality of training in Côte d'Ivoire and the perceptions related to foreign education (especially in France and Switzerland) are also important factors underlined by the participants. The impact of the quality of training on Ivorian students' migration can be seen at two levels: the attractiveness of the French higher education system and other OECD countries, and the poor quality of training in Côte d'Ivoire.

The French higher education system is highly valued in Côte d'Ivoire. Studying in France is seen as a guarantee of quality and expertise. Indeed, the participants argued that French universities offer practical training to turn students into professionals in their fields. This training included practical courses and internship opportunities. They look for a fit with labour market demands. Our interviewees also emphasized French university professors' professionalism, especially in the supervision of research work in masters and doctorate programmes that contribute to the positive reputation of French diplomas. Conversely, the training content in Côte d'Ivoire is unsatisfactory because the knowledge is too theoretical. Participants sometimes criticize university professors' skills. The same goes for their commitment to supervise students' research:

In Côte d'Ivoire, there are many university professors who do not like hard work. They are on strike very often for their bonuses when they are not hard workers. They do not care about their students. (Abou, Department of Law, University Félix Houphouët-Boigny)

According to the students, the relation between MA and PhD students and their supervisors is restrictive and conflictual, and it constitutes a push factor. Students particularly stress their difficulties communicating and collaborating regularly and efficiently with their supervisors, who do not let them develop their ideas and research projects. Similarly, the learning conditions and the availability of pedagogical resources are also seen negatively, and the students face some problems in obtaining access to updated and relevant scientific literature.
The perceptions of the Ivorian diplomas truly contrast with the social representations related to foreign diplomas. For Ivorian students, obtaining a foreign diploma (especially from a renowned northern university) could facilitate their socio-professional integration in the local labour market. There is a widespread perception that in Côte d'Ivoire, recruiters give priority to those who hold foreign diplomas. In addition, these diplomas are expected to enable them to obtain quick access to higher professional positions. Therefore, student migration represents an effective means to improve and broaden employment opportunities in the domestic labour market:

Professional prospects matter a lot. Going to France increases your chances in the labour market. When you have studied in France, you have more opportunity to quickly obtain a valued job and to be well paid. (Eric, Department of Communication, Catholic University of West Africa)

Conversely, the Ivorian diploma looks less valuable because of the quality of training and Ivorian universities' weak reputation, despite the huge investments of the Ivorian government. All these dysfunctions mentioned above encourage many Ivorian students to consider going abroad.

\subsection{Migration Networks, Decision-Making Process and Realization of Migration Project}

Decision-making, selection of host countries and effective realization of a migration project involve networks that encourage students to migrate and provide them with a set of resources. Migration decision-making is often a consequence of a network's action, which incites students to move abroad or make decisions for them. Generally, the migration of high school graduates and bachelor's degree students results from a decision made by the family. In line with predictions by Touré (2015), this decision is described by the students interviewed as a strategic step adopted by the family to avoid the difficulties of the Ivorian higher education system and to benefit from the prestige of the European tertiary educational system. In addition, the elites have established a mobility tradition in their families, which leads parents to send their children abroad as soon as they graduate from Ivorian high schools. In that respect, these wealthy families perceived student migration to France as a natural step in their children's academic trajectories:

My older brothers studied in France. For me, it is obvious to go there, to start my higher education studies there before going somewhere else. We do not even consider staying in Cote d'Ivoire and being enrolled in a local university. (Alida, Saint Marie High School, Abidjan) 
Otherwise, Ivorian students who have previously studied or are currently studying in French universities play a key role in promoting the French higher education system. Indeed, they present to their friend and relatives a positive and sometimes idealized view of French universities. In doing so, they emphasize the positive aspect of these universities, the quality of courses, availability and diversity of educational resources, and professionalism and competencies of university staff members, and hide the bad aspects related to their staying abroad, like budget constraints, administrative and immigration procedures, loneliness and homesickness.

The success story of some graduates returning from France reinforces the attraction for this destination. Generally, these graduates share their experiences with those remaining in Côte d'Ivoire, highlighting their brightest aspects. Given that Ivorian youths are strongly attracted by the Western way of life, these experiences can create some deep desires to leave:

I have many friends who moved to France. They incited me to move too, but I was not interested....They sent me pictures via Facebook, and they took some photographs in their beautiful campus and in very fantastic and famous places like the Parc des Princes. What a dream! Finally, they convinced me to move abroad, and I plan to do it as soon as I gathered enough financial resources. (Paul, University Alassane Ouattara, Bouaké)

More interestingly, high school teachers and university professors encourage their students to move abroad. University professors generally recommend mobility to their students to pursue their specializations and gain strong, valuable expertise. Indeed, they share their own experience of student mobility and underline the positive consequences of studying abroad for their academic and professional careers. Generally, the most esteemed professors in Ivorian universities have completed a great part of their studies abroad (France, the United States, Canada, etc.). They represent a role model for local students who want to follow their successful path and could be an effective prescriber of international student mobility. Migration networks play a significant role in the selection of host countries. However, other important factors vary from one host country to another lead Ivorian students in the choice of their potential host countries.

\subsection{Choose France, a 'Natural' Option}

The preference for France strongly depends on the influence of migration networks. However, other factors, such as the cultural proximity between France and Côte $d^{\prime}$ Ivoire (which is a result of the colonial past mainly reflected by the shared language), the standard of living and the marketing of Campus France also play a decisive role. France is thus viewed as a 'natural' destination. In addition, many Ivorian students have relatives living there, which represents an important asset for migration candidates. These family members can help them realize their migration project by providing them with information and facilitating their social integration in the foreign destination. Indeed, many Ivorian youths seem close to and familiar with France, even if they have never been there:

In France, I target one of the best business schools in the world [HEC Paris]. France is one of the most attractive destinations for Ivorian students because of cultural, linguistic and historical proximity. It is smart and pleasant, and I will not feel out of place because I have already been in this country and I have many friends there. (Isaac, a graduate of the Polytechnic Institute Houphouët-Boigny of Yamoussoukro)

It should be noted that the prestige of some public universities (Paris 1 Panthéon Sorbonne) or private business schools (HEC Paris) attracts Ivorian students who truly want to join their powerful alumni networks at the end of their studies.

\subsection{Accept All the Possibilities}

While France and Switzerland are particularly attractive to Ivorian students, they also look for opportunities from several countries in the north (the United States, Great Britain and Canada) and the south (Morocco, India, Saudi Arabia). During the interviews, we realized that the name of the destination country for some students does not matter as long as they enjoy good training and living conditions. This new migration trend is illustrated by the fact that many students chose to apply simultaneously for multiple scholarships provided by foreign embassies. Moreover, some northern African destinations (for instance, Morocco or Algeria) could represent a transit to OECD universities.

\subsection{Stand Out by Choosing Switzerland}

Ivorian student migration is generally based on a logic of social distinction. In fact, France is sometimes presented as an ordinary destination by students who prefer Switzerland (Renggli \& Riaño, 2017). They perceived Swiss diplomas as rare and more precious because of the reputation of Switzerland in some fields such as finance, medical sciences, and the excellent ranking of Swiss universities in the Shanghai Index. In their view, the Swiss label is a precious symbolic capital that must be acquired:

I think there is a difference between moving to France and moving to Switzerland. When someone goes to Switzerland, he is not housed in the same boat that someone who goes to France. France is an ordinary destination, but Switzerland is a more prestigious destination. (Alex, recipient of a scholarship from the University of Basel) 
Even if Ivorian students express a strong desire to study abroad, many plan to return to their country at the end of their studies. They particularly expressed the willingness to put the skills acquired abroad to their home country's service and enjoy a pleasant life among their family members and relatives.

\subsection{Resources Provided by Migration Networks}

The realization of a student migration project is a complex process for youth who deeply rely on their network to provide them with strategic resources (information, financial and administrative support and integration guidance). Migration networks are essential providers of information about scholarship opportunities, the benchmark of destination countries and universities, and enrolment and immigration procedures. Ivorian international students living in France and diaspora family members appear to be a key part of these information networks.

Families also provide financial support, which is essential for the realization of the migration project. Parents partially or totally finance expenses related to immigration procedures, the university's enrolment process, and the cost of living abroad. Without this familial or hypothetical scholarship, it would be difficult for youth to realize their project to study abroad. This financial dependency explains why the family plays a decisive role in the decision-making process:

I have the full support of my family. I talked to my father and he is ready to provide me with financial support to realize my dream. In addition, I plan to earn my own money when I [am] in France. (Luc, a graduate of the Polytechnic Institute Houphouët-Boigny of Yamoussoukro)

The support of the family, especially at the financial level, remains decisive, despite the presence of the other actors of the network and even sometimes when the student has his own financial means.

\section{Discussion and Conclusion}

Carrying out the field survey in Côte d'Ivoire allowed us to produce an analysis mainly based on the perceptions of students who plan to move abroad. However, the experiences of Ivorian international students (interviewed in France or Switzerland) have enriched the phenomenon's understanding. In addition, the interest of this study is especially emphasized by the scarcity of research on student mobility in Africa and particularly on the influence of migration networks on the realization of such mobility.

As illustrated by the results of this study, international student migration from Africa to northern countries is generally a product of the combination of push factors observed in home countries and pull factors, which characterize northern countries. Many push and pull factors presented in the analysis of the Senegalese (Fall, 2010) and Malian (Mary, 2014) cases appear in our analysis: The low quality of the higher education system, the training conditions in northern countries and the job opportunities deriving from student migration appear to be important factors in international student migration from French-speaking West African countries to northern countries. The uncertainty that arises from the push factors seems to lead many Ivorian students to choose migration to France and Switzerland to access quality training, which can facilitate their professional integration. It was also observed that the potential of student migration in terms of facilitating Ivorian students' professional integration appears to be an interesting research avenue, given that several participants underlined the value of foreign diplomas on the Ivorian labour market.

Moreover, perceptions deriving from pull and push factors look to be key parts of the social construction of this type of mobility. This fact appears to be a constant both in the work of Negura (2017): Social representations produced by the push and pull factors incite individuals to choose mobility and to set up strategies in order to achieve their goal.

The growth of Ivoirian student migration illustrates, to some extent, the current dynamics of migration in Côte d'Ivoire. The country, formerly considered a place for immigration, now appears also to be a country of transit and a country of emigration (IOM, 2018). This increase in student mobility does not only concern Côte d'Ivoire, but all the countries of Sub-Saharan Africa. In Nigeria, for instance, there is a $48 \%$ increase of student mobility outflow from 2012 to 2017 (Campus France, 2019). The Democratic Republic of Congo shows an $60 \%$ increase while Sudan, Ghana and Angola respectively have a growth of $63 \%, 44 \%$ and $46 \%$ (Campus France, 2019). France is the first host country of students from Sub-Saharan Africa $(49,736$ students) ahead of the United States (38,628 students). South Africa is the first African host country for sub-Saharan students (Campus France, 2019).

This research also looks to align with Haug's (2008) findings. In fact, migration networks (families and relatives living in home and host countries) have a key role in the decision-making process: They incite (Ivorian) students to move abroad, share some experiences with them or deciding for them. These networks provide a set of resources to the candidates for migration information, financial support, administrative steps, and integration in the potential host countries. Again, we can notice some similarities between the Ivorian case and other West African cases approached in the literature (Dako-Gyeke, 2015; Mankou, 2014; Touré, 2015). However, Haug (2008) does not deal with the influence of push and pull factors, which obviously have an important role in the decision-making process.

Otherwise, the influence of migration networks on the selection of host countries appears as a permanent feature. Through the construction of chain migration 
(Boyd, 1989) and because of colonial history (Fabre \& Tomasini, 2006), some countries become favourite academic places for students belonging to some national communities such as African students from Frenchspeaking countries who generally choose France as the host country. It should be remembered, however, that geographic proximity plays an important role in the selection of the potential host country (even if this is not true in this study).

The increase of Ivorian student mobility outflows, despite the investments of the government lead to questioning the efficiency of these investments. Otherwise, these investments must be accompanied by significant structural changes in order to make the Ivorian academic place more attractive.

\section{Acknowledgments}

The authors warmly acknowledge the Swiss Sub-Saharan Africa Migration (S-SAM) network for supporting this research and its publication.

\section{Conflict of Interests}

The authors declare no conflict of interests.

\section{References}

Baribeau, C., \& Germain, M. (2010). L'entretien de groupe: Considérations théoriques et méthodologiques [Focus group discussion: Theoretical and methodological considerations]. Recherches qualitatives, 29(1), 28-49.

Bereni, M., \& Rubi, B. (2015). Les intentions de mobilité vers la France des jeunes étudiants marocains [The mobility intentions of young Morocan students to France]. Les mobilités étudiantes dans le contexte international, 5, 103-120.

Boyd, M. (1989). Family and personal networks in international migration: Recent developments and networks agendas. International Migration Review, 23(3), 638-670.

Campus France. (2018). Les chiffres clés [The key figures]. Paris: Campus France.

Campus France. (2019). Mobilités et coopérations universitaires en Afrique subsaharienne [Mobilities and university partnerships in sub-Saharan Africa]. Paris: Campus France.

Charlier, J.-É., \& Croché, S. (2010). L'inéluctable ajustement des universités africaines au processus de Bologne [The inevitable adjustment of African universities to the Bologna process]. Revue française de pédagogie/Recherches en education, 172, 77-84. https://doi.org/10.4000/rfp.2276

Cresswell, J. (2014). Research design: Qualitative, quantitative and mixed methods approaches. London: SAGE Publications.

Dako-Gyeke, M. (2015). Exploring the migration inten- tions of Ghanaian youth: A qualitative study. Migration and Integration, 17, 723-744.

Dia, H. (2014). Globalisation et mobilité pour études [Globalization and student mobility]. Hommes et migrations, 1307, 6-7.

Efionayi, D., \& Piguet, E. (2014). Les étudiants d'Afrique de l'Ouest face à la globalisation du savoir [West African students in the face of globalization of knowledge]. International Development Policy/Revue internationale de politique de développement, 5, 1-18.

Fabre, J., \& Tomasini, M. (2006). Les étudiants étrangers en France et français à l'étranger [Foreign students in France and French students abroad]. Données sociales: La société française. Retrieved from file://C:/Users/URBANP 1/AppData/Local/Temp/ donsoc06l.pdf

Fall, M. (2010). Migration des étudiants sénégalais. Impact sur le développement de leur pays d'origine [Migration of Senegalese students. Impact on the development of their country of origin]. Hommes et migrations. https://doi.org/10.4000/ hommesmigrations.1755

Gérard, M., \& Voin, M. (2013). La mobilité étudiante et ses conséquences pour l'internationalisation du marché du travail [Student mobility and its consequences for the internationalization of the labor market]. Reflets et perspectives de la vie économique, 4(52), 61-79.

Haug, S. (2008). Migration networks and migration decision-making. Journal of Ethnic and Migration Studies, 34(4), 585-605.

IOM. (2018). Rapport de profilage des migrants ivoiriens 2017 [Ivorian migrants profiling report 2017]. Geneva: International Organization for Migration.

Kabbanji, L., Levantino, A., \& Ametepe, F. (2013). Migrations internationales étudiantes ghanéennes et sénégalaises: Caractéristiques et déterminants [Ghanaian and Senegalese international student migration: Characteristics and determinants]. Cahiers québécois de démographie, 42(2), 303-333.

King, R., \& Raghuram, P. (2012). International student migration: Mapping the field and new research agendas. Population, Space and Place, 19(2), 127-137.

Mankou, B. A. (2014). Mobilités étudiantes et lien social: Les étudiantes non boursières camerounaises dans le Nord-Pas-de-Calais [Student mobility and social ties: Cameroonian female students without scholarship in the Nord-Pas-de-Calais]. Hommes et migrations, 1307, 67-74.

Mary, K. (2014). Le retour difficile des jeunes Maliens formés en Amérique du Nord [The difficult return of young Malians trained in North America]. Hommes et migrations, 1307, 39-46.

Mazzella, S. (2016). Sociologie des migrations [Sociology of migrations]. Paris: Puf.

Merriam, S. B., \& Tisdell, E. J. (2016). Qualitative research: $A$ guide to design and implementation (4th ed.). San Francisco, CA: Jossey-Bass. 
Negura, L. (2017). La construction sociale de la migration: Le rôle de l'expérience et des représentations sociales [Social construction of migration: The role of experience and social representations]. Canadian Ethnic Studies, 49(1), 103-124.

Razafimahefa, L., \& Raynal, J.-C. (2014). Dynamique des réseaux de mobilité étudiante entre pays du Sud: Attractivité, compétitivité et multipolarité [Dynamics of student mobility networks between Southern countries: Attractiveness, competitiveness and multipolarity]. Cahiers de la recherche sur l'éducation et les savoirs, 13, 25-52.

Renggli, C., \& Riaño, Y. (2017). Mobilité étudiante inter- nationale: Raisons d'étudier en Suisse, stratégies, expériences et projets d'avenir [International student mobility: Reasons for studying in Switzerland, strategies, experiences and future plans]. Géo-Regards: Revue neuchâteloise de géographie, 10, 71-91.

Touré, N. (2015). L'approche "reseaux" dans les études migratoires: Un cas d'étude des trajectoires scolaires des étudiants maliens en France et au Maroc [The 'network' approach in migration studies: A case study of the school trajectories of Malian students in France and Morocco]. https://doi.org/10.4000/ e-migrinter.549

\section{About the Authors}

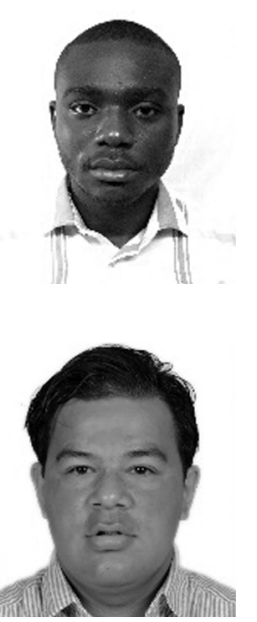

Franck Dago is a PhD student at the Department of Sociology of the University Félix Houphouët-Boigny of Abidjan, Côte d'Ivoire. He belongs to the Swiss Sub-Saharan Africa Migration (S-SAM) network. His research is related to transnational communities in West Africa, student migration and qualitative analysis.

Simon Barussaud (PhD) is a Swiss and Burkinabe Researcher who holds a PhD in Socioeonomics from the University of Geneva. Living in Côte d'Ivoire since 2016, he belongs to the Swiss Sub-Saharan Africa Migration (S-SAM) network. His research focus on migration, youth employment, vocational training and informal economy. Author of several publications on these different topics (e.g., La formalisation vue d'en bas: Enjeux pour la transition vers l'économie formelle, 2019, edited by S. Barussaud and F. Lapeyre), he currently works as an international consultant for the ILO, the FAO and the IOM. 